\title{
ANALISIS HUBUNGAN FAKTOR INDIVIDU DAN BEBAN KERJA MENTAL DENGAN STRES KERJA
}

\section{CORRELATION OF INDIVIDUAL FACTORS AND MENTAL WORKLOAD WITH JOB STRESS}

\author{
Intan Sulistyana Mustika Suci \\ PT. Safila Arta Nugraha \\ E-mail: intansulistyanams@gmail.com
}

\begin{abstract}
Stress is the stimulation of the situation which could threaten the physical and psychological that cannot be tolerated by an individual because of limited ability. The general objective of this research is to analyze the individual factors and mental workload with stress. The research was done in observational. Population in this study are all the workers are there in packer PT. X amount of 10 workers and analysis of the data used is the spearman correlation test to known the correlation between education and mental workload with job stress, pearson correlation test to known the correlation between age and work period with job stress and contingency test to known the correlation between marital status with job stress. Based on the results of the statistical tests, a variable that has a strong relationship with stress is mental work load variable (0.667), while variables that have a relationship with stress is the level of education (-0.102), marital status (0.378), the period of employment (-0.102) and age (-0.408). From the results of this research it can be concluded that the majority of respondents in the age range 21-40 years (60\%) and has a working time of 5-9 years (70\%) by level of education finished high school (60\%) and be married (60\%). The relationship between mental workload with the stress of having strong correlation.
\end{abstract}

Keywords: job stress, mental workload

\begin{abstract}
ABSTRAK
Stres adalah rangsangan terhadap situasi yang dapat mengancam fisik dan psikologis yang tidak dapat ditoleransi oleh seorang individu karena keterbatasan kemampuan. Stres dapat terjadi kepada semua unit kerja, termasuk para manajer dan eksekutif juga mengalaminya. Tujuan penelitian ini adalah menganalisis faktor individu dan beban kerja mental dengan stres kerja pada pekerja packer di PT. X. Penelitian ini dilakukan secara observasional kepada pekerja packer di PT. X. Populasi dalam penelitian ini adalah seluruh pekerja packer yang ada di PT. X dengan jumlah 10 pekerja dan analisis data yang digunakan adalah uji korelasi Spearman untuk menguji hubungan variabel tingkat pendidikan dan beban kerja mental dengan stres kerja, uji korelasi pearson untuk menguji hubungan variabel umur dan masa kerja dengan stres kerja dan uji coefficient contingency untuk mengetahui hubungan variabel status perkawinan dengan stres kerja. Berdasarkan hasil uji statistik, variabel yang memiliki hubungan kuat dengan stres kerja adalah variabel beban kerja mental (koefisien 0,667), sedangkan variabel yang memiliki hubungan rendah dengan stres kerja adalah tingkat pendidikan $(-0,102)$, status perkawinan (0,378), dan masa kerja $(-0,102)$. Variabel dengan hubungan sedang adalah variabel umur (-408). Dari hasil penelitian ini dapat disimpulkan bahwa sebagian besar responden pada rentang umur 21-40 tahun (60\%) dan memiliki masa kerja 5-9 tahun (70\%) dengan tingkat pendidikan Tamat SMA (60\%) dan berstatus menikah (60\%). Hubungan antara beban kerja mental dengan stres memiliki hubungan kuat.
\end{abstract}

Kata kunci: beban kerja mental, stres kerja

\section{PENDAHULUAN}

Tenaga kerja merupakan aset yang paling penting bagi perusahaan. Tetapi tidak semua perusahaan memperhatikan kesejahteraan karyawan dan sering kali diabaikan. Tidak jarang perusahaan menganggap karyawan adalah beban yang semestinya harus ditekan untuk mengurangi biaya produksi suatu perusahaan. Tuntutan hidup dan tuntutan perusahaan membuat karyawan menurunnya kesehatan sampai kepada dideritanya suatu penyakit.

Stres dapat terjadi kepada siapa saja dan pada unit kerja apa saja, termasuk para manajer dan eksekutif juga mengalaminya. Diperkirakan 100 
juta hari kerja menjadi sia-sia dikarenakan stres dan hampir $50 \%$ sampai $70 \%$ penyakit berkaitan dengan stres (Tahir, 2015). Survei yang telah dilakukan pada perusahaan asuransi Northwestren National menunjukkan bahwa 7 dari 10 pekerja mengindikasikan bahwa stres yang dialami menyebabkan masalah kesehatan dan kurang produktifnya pekerjaan. Berdasarkan hasil survei 1 dari 3 pekerja Amerika Serikat mempertimbangkan keluar dari pekerjaannya karena stres akibat faktor yang berkaitan dengan tempat kerja, 1 dari 10 pekerja dihadapkan dengan berbagai masalah sehingga dapat membuat karyawan terkena stres. Health Safety Executive (2008) yang dikutip dalam Tarwaka (2015), stres adalah reaksi negatif manusia yang diakibatkan dari berbagai masalah dan tekanan yang berlebihan atau jenis tuntutan lainnya. Stres akan berubah menjadi hal positif apabila seseorang dapat mengendalikannya, akan tetapi apabila orang tersebut tidak bisa mengendalikan dengan baik akan dapat mengakibatkan berbagai masalah salah satunya adalah gangguan kesehatan.

Perkembangan teknologi komputerisasi membuat penggunaan peralatan kerja yang digunakan bersifat otomatis. Banyak keuntungan yang diperoleh dari pemanfaatan teknologi ini, salah satunya adalah hasil produksi yang dihasilkan lebih banyak dan menghemat biaya produksi. Terdapat juga kerugian dengan adanya peralatan yang dapat dioperasikan secara otomatis. Pengoperasian peralatan secara otomatis membuat pekerja hanya sedikit mendapat peran dalam proses produksi. Beban kerja yang terlalu banyak atau terlalu sedikit membuat seseorang mengalami stres kerja.

Menurut Robbins (2004), stres kerja adalah beban kerja yang berlebihan, perasaan susah dan ketegangan emosional yang menghambat performance individu. Stres kerja menyebabkan gangguan fisik maupun gangguan psikologis. Gangguan psikologis yang sering terjadi sebagai akibat dari stres kerja adalah kecemasan dan depresi (Wijono, 2010). Menurut Manuaba (1998), stres adalah segala aksi dari tubuh manusia baik yang berasal dari luar maupun dari dalam tubuh itu sendiri yang dapat menimbulkan bermacammacam dampak yang merugikan mulai dari keluar dari tempat kerjanya karena stres akibat faktor non pekerjaan, dan $46 \%$ menyatakan bahwa pekerjaan mereka sangat penuh dengan stres (Suci, 2012).

Perkembangan teknologi komputerisasi, membuat peralatan yang dikendalikan oleh operator bersifat otomatis. Kemajuan teknologi memperlambat kemampuan manusia untuk mempertahankan produktivitas sehingga lebih rentan mengalami stres kerja (Pratiwi, 2013). Berdasarkan hasil survei ahli kesehatan, 60-90\% dari pengunjung rumah sakit mengeluhkan penyakit terkait stres kerja seperti: sakit kepala, gastrointestinal, pegal pada bagian tulang belakang, dan penyakit kardiovaskular (Suisky, 2005).

Dampak stres kerja bila tidak ditangani dengan baik maka seseorang akan cenderung menjadi pemarah, terjadi gangguan mental, gangguan fisiologis, dan dapat menyebabkan gangguan pada organisasi atau tempat kerja berupa penurunan kinerja dan produktivitas hingga menyebabkan kecelakaan kerja (Tarwaka, 2010). Beban kerja harus disesuaikan dengan kemampuan pekerja, jika beban kerja terlalu rendah atau terlalu tinggi maka produktivitas kerja juga akan redah (Tarwaka, 2010).

Packer adalah unit kerja di PT. X Tuban yang bertugas menempatkan kantong semen pada alat pengisi semen yang bekerja secara otomatis mengisi kantong semen kosong dengan produk semen yang sudah jadi. Pekerjaan di bagian ini dilakukan dengan berdiri selama jam kerja yaitu selama 8 jam setiap hari. Terdapat target kantong semen yang harus terisi setiap harinya yaitu sekitar 2000 kantong/jam. Adanya target produksi dan tuntutan waktu yang harus dipenuhi oleh pekerja membuat beban kerja mental di bagian Packer meningkat, kurangnya variasi kerja di bagian packer membuat pekerja mudah jenuh dan bosan melakukan pekerjaan.

Beban kerja berlebih dan beban kerja terlalu sedikit juga dapat menjadi faktor pembangkit terjadinya stres. Menurut Herrianto (2010), faktor yang membuat seseorang menjadi stres meliputi sistem tugas yang melebihi kemampuan pekerja, volume pekerjaan yang berlebih, tanggung jawab yang terlalu berat, kondisi fisik/lingkungan kerja yang Ekstrem dan organisasi tempat kerja yang kurang mendukung. Salah satu faktor yang bersumber pada pekerjaan diantaranya beban kerja.

Beban kerja mental yang diterima di bagian packer seperti membaca surat ijin pengeluaran semen permintaan dari distributor. Permintaan produk semen setiap daerah atau distributor berbeda, hal ini dibutuhkan ketelitian saat membaca agar tidak salah membaca permintaan produk semen. Andraeni (2003), menyebutkan bahwa beban kerja berlebih dan beban kerja terlalu sedikit dapat menjadi faktor pembangkit terjadinya stres. 
Cox \& Gonzales (2000), mengelompokkan bahaya menjadi dua yaitu bahaya fisik dan bahaya psikososial. Beberapa tahun terakhir, organisasi internasional telah meningkatkan kesadaran mengenai risiko psikososial pekerjaan yang berhubungan dengan stres kerja, tetapi pada pelaksanaannya di tingkat perusahaan masih ada kesenjangan (Prativi, 2013).

Kemajuan teknologi komputerisasi membuat kerja manusia lebih sedikit sehingga memperlambat kemampuan manusia untuk mempertahankan produktivitas sehingga lebih rentan mengalami stres kerja (Prativi, 2013). Berdasarkan penelitian cross-sectional dari Journal of Psychosomatic Research (2006) menunjukkan sebanyak 35\% dari populasi sampel dari pekerja pabrik mengalami masalah kesehatan seperti kecemasan, gangguan tidur, depresi, keluhan somatik dan indikator klinis lain dari stres.

Penelitian yang pernah dilakukan oleh Prabawati (2012) dengan judul Hubungan Beban Kerja Mental dengan Stres Kerja Pada Perawat Bagian Rawat Inap RSJD Dr. R. M. Soedjarwadi Klaten. Hasilnya yaitu terdapat hubungan antara beban kerja mental dengan stres kerja pada perawat di bagian rawat inap.

PT. X adalah perusahaan yang memproduksi semen yang digunakan untuk bahan baku dalam pembangunan. Proses produksi dimulai dari penambangan batu kapur, tanah liat yang merupakan bahan baku utama pembuatan semen. Sampai ke proses penggilingan, pembakaran dan pengepakan, sehingga siap untuk didistribusikan ke pelosok Indonesia.

Berdasarkan hasil observasi pada 15 Maret 2017, di PT. X pekerja di bagian packer harus menempatkan kantong semen pada alat pengisi semen \pm 2000 kantong setiap jam. Tuntutan tugas yang terlalu besar dan melebihi batas kemampuan individu dapat menyebabkan stres kerja. Hasil wawancara terhadap beberapa pekerja yang ada di bagian packer tentang masalah kesehatan yang biasa terjadi misalnya adalah sakit kepala, flu, sakit punggung, dan gangguan lambung. Berdasarkan penelitian yang dilakukan oleh Hanapi, (2014) penyebab beban kerja mental di bagian front staff adalah tuntutan kerja sebesar $20 \%$, jenis pekerjaan sebesar $40 \%$ dan tuntutan waktu sebesar $40 \%$. Tuntutan kerja di bagian front staff yang dapat menjadi penyebab beban kerja mental adalah pemenuhan target produksi dari perusahaan yang harus dipenuhi. Sama halnya dengan tuntutan kerja yang ada di bagian packer dan loader ini, pekerja harus menyelesaikan tuntutan produksi semen di bagian packer \pm 2000 kantong semen/jam. Banyaknya permintaan distributor juga termasuk salah satu penyebab beban kerja mental tinggi di bagian packer. Terlebih saat menjelang hari raya, permintaan semen dari distributor meningkat dan membuat pekerja harus mengejar waktu untuk menyelesaikan target produksi.

Target produksi yang besar, memberikan tekanan yang berat bagi pekerja di bagian packer ini. Selain itu, operator packer bekerja di bawah pengawasan kepala bagian. Sering kali mereka ditegur karena melakukan kesalahan, ini memberikan tekanan secara psikologis pada operator. Pekerjaan di bagian packer yang berkaitan dengan aktivitas mental misalnya pekerja harus membaca surat ijin permintaan semen dari distributor, setiap distributor memiliki permintaan jumlah semen yang berbeda. Selain itu, diperlukan konsentrasi dalam melakukan pengisian semen, apabila pekerja kehilangan konsentrasi sehingga menempatkan kantong pada alat pengisian semen tidak tepat, semen dapat menyembur ke arah pekerja dan dapat menyebabkan kecelakaan kerja.

Faktor lain yang dapat menjadi penyebab stres kerja adalah status pernikahan seseorang dapat menjadi faktor pemicu terjadinya stres di tempat kerja. Seorang pekerja yang sudah menikah tidak hanya memikirkan kebutuhan hidupnya sendiri, akan tetapi harus memikirkan kebutuhan hidup keluarganya juga. Umur seorang pekerja juga dapat menjadi penyebab stres kerja, karena seseorang dengan umur yang masih muda cenderung mudah terpancing dan belum bisa mengendalikan emosi dengan baik. Keahlian, pengalaman kerja juga dibutuhkan agar pekerja dapat melaksanakan tugas dengan baik dan dapat mencapai target produksi yang diberikan oleh perusahaan. Sesuai dengan penelitian yang dilakukan oleh Astuti (2015) yang menyebutkan bahwa variabel yang berhubungan dengan stres kerja adalah umur, masa kerja, dan upah/ pendapatan.

Penelitian yang dilakukan oleh Mutia (2014) menyebutkan bahwa pekerjaan di bagian operator pengepakan dengan metode Nasa-TLX didapatkan total rating masing-masing indikator termasuk ke dalam beban kerja mental tinggi. Penyebab beban kerja mental di operator packer lebih diakibatkan oleh tuntutan produksi dan tuntutan waktu untuk mengejar target produksi yang dibebankan kepada pekerja. 
Penelitian ini bertujuan untuk menganalisis faktor individu dan beban kerja mental dengan stres kerja pada pekerja packer di PT. X, sehingga perusahaan dapat melakukan tindakan pencegahan atau preventif agar pekerja selalu merasa nyaman dan produktivitas kerja meningkat.

\section{METODE}

Penelitian ini termasuk penelitian observasional yaitu hanya mengamati dan mencatat gejala yang berhubungan dengan penelitian (Notoatmodjo, 2002). Analisis penelitian bersifat deskriptif karena hanya menggambarkan secara objektif, sistematis, faktual dan akurat fakta yang diteliti (Notoatmodjo, 2002). Sampel dari penelitian ini adalah seluruh pekerja shift pagi di bagian packer yang berjumlah 10 orang. Sampel diambil dengan metode total sampling karena jumlah yang tidak terlalu banyak dan memungkinkan untuk digunakan penelitian dengan total populasi.

Variabel pada penelitian ini adalah karakteristik individu (umur, tingkat pendidikan, status perkawinan, masa kerja), beban kerja mental, dan stres kerja. Pengumpulan data dilakukan dengan teknik wawancara dan bantuan kuesioner.

Untuk mengetahui hubungan antara variabel beban kerja mental dengan stres kerja dilakukan dengan menggunakan tabulasi silang (cross tab). Data yang diperoleh dari kuesioner kemudian dianalisis dengan tabel narasi. Untuk mengetahui kuat hubungan antara variabel status perkawinan dengan stres kerja digunakan metode Contingency Coefficient. Variabel umur dan masa kerja dengan stress kerja menggunakan uji korelasi pearson, dan untuk variabel tingkat pendidikan dan beban kerja mental dengan stres kerja menggunakan uji korelasi spearman.

\section{HASIL}

\section{Gambaran Umum Perusahaan}

PT X Tuban adalah perusahaan yang bergerak di bidang industri semen. Pertama kali didirikan memiliki kapasitas produksi 250.000 ton semen per tahun. Saat ini kapasitas terpasang sebesar 16,92 juta ton semen per tahun, dan menguasai sekitar $46 \%$ pangsa pasar. Perusahaan ini memproduksi beberapa jenis semen diantaranya yaitu semen portland tipe 1 sampai dengan 5, special blended cement, portland pozzolan cement (PPC).
Dalam mewujudkan efektivitas dan efisiensi tata kelola, Perseroan telah menerapkan manajemen terintegrasi dengan mengacu pada prinsip-prinsip tata kelola perseroan yang baik (good corporate governance), yaitu Sistem Manajemen Mutu (ISO 9001), Sistem Manajemen Lingkungan (ISO 14001), Sistem Manajemen K3 (SMK3- OHSAS 18001), Sistem Manajemen Laboratorium Pengujian (ISO/ IEC 17025), Sistem manajemen Risiko (ISO 31000), dan Sistem Manajemen Keselamatan Pertambangan serta Program-program peningkatan melalui penerapan Manajemen Inovasi.

Penerapan Sistem Manajemen di PT. X, diharapkan mampu meningkatkan nilai tambah bagi pemegang saham dan pemangku kepentingan (stakeholders) yang lain pada umumnya.

\section{Distribusi Umur Responden}

Distribusi umur responden pada Tabel 1 berada pada rentang umur 21-40 tahun sebanyak 6 responden $(60 \%)$, pada rentang umur tersebut tergolong muda, mempunyai semangat tinggi dan performa tenaga terbaik sehingga produktivitas responden masih tergolong tinggi. Oleh karena itu PT. X cenderung mempekerjakan karyawan dengan umur 21-40 tahun meskipun masih terdapat pekerja yang berumur 41-60 tahun.

\section{Distribusi Tingkat Pendidikan}

Distribusi tingkat pendidikan responden Packer di PT. X dapat ditunjukkan pada Tabel 2. Distribusi tingkat pendidikan responden sebagian besar Tamat SMA yaitu sebanyak 6 responden (60\%). Pekerjaan di bagian packer lebih dituntut untuk memiliki keahlian dibandingkan dengan pendidikan formal

Tabel 1. Distribusi Umur Responden Packer PT. X 2017

\begin{tabular}{rcc}
\hline Umur & Frekuensi & Persentase (\%) \\
\hline $21-40$ tahun & 6 & 60 \\
$41-60$ tahun & 4 & 40 \\
\hline Total & 10 & 100 \\
\hline
\end{tabular}

Tabel 2. Distribusi Tingkat Pendidikan Pesponden Packer PT. X, 2017

\begin{tabular}{lcc}
\hline Tingkat Pendidikan & Frekuensi & Persentase (\%) \\
\hline Tamat SMP & 4 & 40 \\
Tamat SMA & 6 & 60 \\
\hline Total & 10 & 100 \\
\hline
\end{tabular}


Tabel 3. Distribusi Status Perkawinan Responden di Bagian Packer PT. X 2017

\begin{tabular}{lcc}
\hline Status Perkawinan & Frekuensi & Persentase (\%) \\
\hline Menikah & 4 & 40 \\
Belum Menikah & 6 & 60 \\
\hline Total & 10 & 100 \\
\hline
\end{tabular}

Tabel 4. Distribusi Masa Kerja Responden di PT. X, 2017

\begin{tabular}{lcc}
\hline \multicolumn{1}{c}{ Masa Kerja } & Frekuensi & Persentase (\%) \\
\hline 0-4 tahun & 3 & 30 \\
$5-9$ tahun & 7 & 70 \\
\hline Total & 10 & 100 \\
\hline
\end{tabular}

Tabel 5. Distribusi Beban Kerja Mental Responden di PT. X, 2017

\begin{tabular}{lcc}
\hline Beban Kerja Mental & Frekuensi & Persentase (\%) \\
\hline Sedang & 9 & 90 \\
Berat & 1 & 10 \\
\hline Total & 10 & 100 \\
\hline
\end{tabular}

yang tinggi sehingga responden cenderung tidak melanjutkan pendidikan lebih tinggi seperti di perguruan tinggi. Keahlian yang dibutuhkan dapat dipelajari, seiring dengan masa kerja responden maka akan semakin meningkat keahlian dalam bekerja. Pekerjaan di bagian packer termasuk pekerjaan yang tidak membutuhkan pekerja dengan pendidikan yang tinggi akan tetapi lebih membutuhkan keterampilan atau skill dibandingkan dengan pendidikan formal.

\section{Distribusi Status Perkawinan}

Distribusi status perkawinan responden dapat dilihat dalam Tabel 3.Sebagian besar responden berstatus belum menikah yaitu sebanyak 6 responden $(60 \%)$. Status perkawinan tidak terlalu diperhatikan atau tidak termasuk dalam kriteria penerimaan pekerja di PT. X Tuban. Pekerja packer sebagian besar belum menikah, tetapi masih terdapat pekerja yang sudah menikah. Status perkawinan memang biasanya berpengaruh bagi seseorang, karena apabila seseorang sudah memiliki keluarga maka tanggung jawab dan kewajiban tidak hanya pada dirinya sendiri tetapi juga pada keluarganya. Hal tersebut memberikan beban tersendiri ketika melakukan pekerjaan.

\section{Distribusi Masa Kerja}

Distribusi masa kerja responden di bagian Packer ditunjukkan pada Tabel 4. Masa kerja sebagian responden adalah 5-9 tahun yaitu sebanyak 7 responden (70\%). Pergantian pekerja oleh PT. X Tuban biasanya dilakukan secara bersamaan, oleh karena itu banyak pekerja yang memiliki masa kerja sama. Semakin lama masa kerja maka semakin berpengalaman seorang pekerja tersebut.

\section{Distribusi Beban Kerja Mental}

Tabel 5 menjelaskan bahwa responden mengalami beban kerja mental sedang yaitu sebanyak 9 responden (90\%). Menurut operator mesin packer beban kerja yang berhubungan dengan mental yang diperoleh dalam pekerjaan adalah ketelitian saat membaca surat ijin pengeluaran semen dari distributor, permintaan semen dari masingmasing distributor berbeda. Setiap daerah memiliki kode wilayah berbeda karena untuk menentukan kantong semen jenis apa yang digunakan di daerah masing-masing sehingga dibutuhkan ketelitian dalam membaca surat ijin pengeluaran semen dan dalam memasukkan jumlah permintaan semen secara otomatis pada mesin pengisian semen. Target produksi dan tuntutan waktu yang harus terpenuhi membuat beban mental tersendiri bagian operator packer.

\section{Tabulasi Silang Faktor Individu dan Beban Kerja Mental dengan Stres Kerja}

\section{Hubungan Umur dengan Stres Kerja}

Berdasarkan hasil penelitian nilai koefisien korelasi pearson untuk bagian packer adalah $-0,408$. Artinya hubungan antara umur dengan stres kerja responden di bagian packer adalah sedang. Tanda minus (-) menunjukkan hubungan berlawanan arah yang artinya semakin tinggi umur responden maka semakin rendah tingkat stres kerja yang didapatkan. Hal tersebut dapat dilihat dari tabel 6 yang menunjukkan bahwa responden yang mengalami stres kerja sedang dan berumur 21-40 tahun sebanyak 5 responden $(83,3 \%)$ dan untuk responden yang berumur 41-60 tahun sebanyak 3 responden $(75 \%)$.

Responden yang mengalami stres kerja tinggi dan berumur 21-40 tahun sebanyak 1 responden 
Tabel 6. Tabulasi Silang Karakteristik Individu dan Beban Kerja Mental dengan Stres Kerja di Bagian Packer PT. X Tuban, 2017

\begin{tabular}{|c|c|c|c|c|c|c|}
\hline \multirow{3}{*}{ Faktor } & \multicolumn{4}{|c|}{ Stres } & \multirow{2}{*}{\multicolumn{2}{|c|}{ Total }} \\
\hline & \multicolumn{2}{|c|}{ Sedang } & \multicolumn{2}{|c|}{ Tinggi } & & \\
\hline & $\mathbf{n}$ & $\%$ & $\mathbf{n}$ & $\%$ & $\mathbf{N}$ & $\%$ \\
\hline \multicolumn{7}{|l|}{ Umur } \\
\hline $21-40$ tahun & 5 & 83,3 & 1 & 16,7 & 6 & 100 \\
\hline $41-60$ tahun & 3 & 75 & 1 & 25 & 4 & 100 \\
\hline \multicolumn{7}{|c|}{ Tingkat Pendidikan } \\
\hline Tamat SMP & 3 & 75 & 1 & 25 & 4 & 100 \\
\hline Tamat SMA & 5 & 83,3 & 1 & 16,7 & 6 & 100 \\
\hline \multicolumn{7}{|c|}{ Status Perkawinan } \\
\hline Menikah & 4 & 66,7 & 2 & 33,3 & 6 & 100 \\
\hline $\begin{array}{l}\text { Belum } \\
\text { Menikah }\end{array}$ & 4 & 100 & 0 & 0 & 4 & 100 \\
\hline \multicolumn{7}{|l|}{ Masa Kerja } \\
\hline $0-4$ tahun & 3 & 100 & 0 & 0 & 3 & 100 \\
\hline 5-9 tahun & 5 & 71,4 & 2 & 28,6 & 7 & 100 \\
\hline \multicolumn{7}{|c|}{ Beban Kerja Mental } \\
\hline Sedang & 8 & 88,9 & 1 & 11,1 & 9 & 100 \\
\hline Tinggi & 1 & 100 & 0 & 0 & 1 & 100 \\
\hline
\end{tabular}

$(16,7 \%)$ dan responden dengan umur 41-60 tahun sebanyak 1 responden $(25 \%)$.

\section{Hubungan Tingkat Pendidikan dengan Stres Kerja}

Berdasarkan Tabel 6 tentang tabulasi silang antara tingkat pendidikan dengan stres kerja, menunjukkan bahwa responden dengan status tamat SMP (25\%) lebih banyak mengalami stres kerja tinggi dibandingkan dengan responden yang tamat SMA $(16,7 \%)$. Hasil uji statistik menunjukkan bahwa koefisien korelasi spearman hubungan tingkat pendidikan dengan stres kerja di bagian packer menunjukkan nilai $-0,102$ yang artinya hubungan antara tingkat pendidikan dengan stres kerja adalah sangat rendah. Tanda minus (-) menunjukkan hubungan terbalik yang artinya semakin rendah tingkat pendidikan maka semakin tinggi stres kerjanya.

\section{Hubungan Status Perkawinan dengan Stres Kerja}

Hasil penelitian ini menunjukkan bahwa sebagian besar responden sudah berstatus menikah yaitu sebanyak 6 responden dari yang menikah tersebut sebagian besar mengalami stres kerja sedang yaitu sebanyak 5 responden $(83,3 \%)$ dan 1 responden mengalami stres kerja tinggi (16,7\%). Responden yang berstatus belum menikah sebanyak 4 responden mengalami stres kerja sedang $(100 \%)$. Nilai contingency coefficient sebesar 0,378 artinya hubungan antara status perkawinan dengan stres kerja adalah rendah.

\section{Hubungan Masa Kerja dengan Stres Kerja}

Hasil penelitian yang dilakukan dapat diketahui bahwa responden dengan masa kerja 5-9 tahun dan mengalami stres kerja sedang sebanyak 5 responden $(71,4 \%)$, sedangkan untuk responden yang memiliki masa kerja $0-4$ tahun dan mengalami stres kerja sedang sebanyak 3 responden (100\%). Untuk responden dengan masa kerja 5-9 tahun dan mengalami stres kerja tinggi sebanyak 2 responden $(28,6 \%)$ dan untuk responden dengan masa kerja 0-4 tahun tidak terdapat mengalami stres kerja tinggi. Hasil uji statistik menunjukkan nilai koefisien korelasi adalah $-0,102$ yang artinya hubungan antara masa kerja dengan stres kerja adalah sangat rendah dan arah korelasinya adalah negatif (-) yang berarti berlawanan arah yaitu semakin lama masa kerja maka semakin rendah stres kerja pada responden.

\section{Hubungan Beban Kerja Mental dengan Stres Kerja}

Hasil penelitian ini menunjukkan bahwa sebagian besar responden yaitu sebanyak 8 responden $(88,9 \%)$ mengalami beban kerja mental sedang dan stres kerja sedang, sedangkan sebanyak 1 responden (100\%) mengalami stres kerja sedang dan beban kerja mental berat. Hasil uji statistik korelasi spearman adalah 0,667 yang artinya hubungan antara beban kerja mental dengan stres kerja adalah sangat kuat. Tanda positif $(+)$ menunjukkan hubungan searah yang artinya semakin tinggi beban kerja maka semakin meningkat stres kerjanya. 


\section{PEMBAHASAN}

\section{Analisis Hubungan Umur dengan Stres Kerja di Bagian Packer}

Hasil penelitian, didapatkan koefisien korelasi pearson untuk bagian packer adalah -0,408. Tanda minus (-) berarti semakin rendah umur seseorang maka semakin tinggi stres kerjanya. Hubungan umur dengan stres kerja menunjukkan bahwa responden yang berumur $21-40$ tahun $(83,3 \%)$ mengalami tingkat stres kerja sedang lebih banyak dibandingkan dengan responden yang berumur 41-60 tahun (75\%), dan responden yang mengalami stres kerja tinggi umur 21-40 tahun (16,7\%) dan umur 41-60 tahun $(25 \%)$.

Hasil penelitian tersebut sejalan dengan penelitian Fitri (2013), bahwa terdapat hubungan antara umur dengan stres kerja. Pekerja yang memiliki umur lebih muda lebih rentan mengalami stres kerja. Pekerja dengan umur yang lebih tua mempunyai pengalaman kerja lebih banyak dibandingkan dengan umur yang relatif muda. Berbeda dengan pendapat Anoraga (2006) yang menyebutkan bahwa semakin tua umur seseorang makan semakin besar kemungkinan untuk mengalami stres kerja, mengingat dengan bertambahnya umur maka semakin kompleks masalah atau persoalan yang dihadapi. Perbedaan hasil penelitian tersebut terjadi karena adanya perbedaan karakteristik responden penelitian. Responden penelitian ini membutuhkan pengalaman yang tinggi guna menanggulangi stres kerja yang disebabkan dari perlakuan manajemen perusahaan. Semakin dewasa umur responden semakin bisa mengontrol emosi dibandingkan dengan responden usia remaja, sehingga responden dengan umur yang lebih tua akan cenderung dapat menanggulangi stres kerja. Perbedaan hasil penelitian ini mungkin disebabkan karena usia yang lebih matang akan lebih mudah untuk mengontrol emosi dan dapat mengambil keputusan secara bijaksana berdasarkan pengalaman yang diperolehnya.

\section{Analisis Hubungan Tingkat Pendidikan dengan Stres Kerja di Bagian Packer}

Hasil uji statistik koefisien korelasi spearman yang diperoleh menunjukkan bahwa hubungan tingkat pendidikan dengan stres kerja di bagian packer menunjukkan nilai -0,102 yang artinya hubungan antara tingkat pendidikan dengan stres kerja adalah sangat rendah. Sejalan dengan penelitian yang dilakukan oleh Wati (2013), diketahui bahwa ada hubungan antara tingkat pendidikan dengan stres kerja dengan $p$ value 0,002 . Tanda minus (-) memiliki arti hubungan terbalik atau berlawanan arah yaitu semakin tinggi pendidikan seseorang maka semakin rendah stres kerjanya. Hasil penelitian ini, menunjukkan bahwa responden dengan status tamat SMP (25\%) mengalami stres kerja tinggi dibandingkan dengan responden yang tamat SMA $(16,7 \%)$. Hasil penelitian lain yang sesuai dengan penelitian ini adalah penelitian yang dilakukan oleh Saikhunudin (2009) tentang stres kerja menyebutkan bahwa tidak ada hubungan kuat antara tingkat pendidikan dengan stres kerja.

Sesuai dengan penelitian yang dilakukan oleh Irkhami (2011) tentang stres kerja pada penyelam menunjukkan bahwa hubungan tingkat pendidikan dengan stres kerja adalah rendah dan semakin tinggi pendidikannya maka semakin rendah tingkat stres kerjanya. Persamaan penelitian ini dengan penelitian lain mungkin dikarenakan untuk meningkatkan pengetahuan dan keterampilan pekerja di bagian packer ini tidak didapatkan dari pendidikan formal melainkan melalui pengalaman dan pelatihan penggunaan mesin produksi setiap harinya.

\section{Analisis Hubungan Status Perkawinan dengan Stres Kerja di Bagian Packer}

Hasil yang didapatkan dari penelitian ini adalah nilai contingency coefficient sebesar 0,378 artinya hubungan antara status perkawinan dengan stres kerja adalah rendah. Sebagian besar responden sudah berstatus menikah yaitu sebanyak 6 responden dari yang menikah tersebut sebagian besar mengalami stres kerja sedang yaitu sebanyak 4 responden $(66,7 \%)$ dan 2 responden mengalami stres kerja tinggi (33,3\%). Hubungan korelasi dapat diartikan bahwa status perkawinan seseorang berpengaruh terhadap terjadinya stres di tempat kerja meskipun status perkawinan responden memiliki hubungan rendah. Evayanti (2003) menyatakan bahwa bagi pekerja yang berstatus menikah, keadaan keluarga bisa menjadi penghambat, mempercepat atau menjadi penangkal proses terjadinya stres.

Penelitian ini sesuai dengan hasil penelitian ini disampaikan oleh Ratnasari (2009),yang menyatakan seseorang yang sudah menikah pasti mempunyai beban yang lebih berat daripada yang belum menikah. Hal tersebut disebabkan karena orang yang sudah menikah tidak hanya memikirkan kebutuhan diri sendiri tetapi juga memikirkan kebutuhan keluarganya sehingga orang yang sudah 
menikah cenderung mempunyai tingkat stres yang lebih tinggi.

Tidak semua individu yang sudah menikah akan mengalami stres saat bekerja karena tergantung kemampuan individu untuk menyelesaikan masalah yang ada dalam keluarga sehingga tidak mengganggu pekerjaannya, sehingga status perkawinan tidak mempunyai hubungan yang kuat dengan stres kerja. Memang responden yang telah menikah akan menanggung kelangsungan hidup keluarganya, tetapi responden tersebut bisa menanggungnya sehingga status perkawinan tidak berhubungan dengan stres kerja.

\section{Analisis Hubungan Masa Kerja dengan Stres Kerja di Bagian Packer}

Hasil uji statistik menunjukkan nilai koefisien korelasi $-0,102$ artinya hubungan antara masa kerja dengan stres kerja adalah sangat rendah dan arah korelasinya adalah negatif (-) yang berarti berlawanan arah yaitu semakin lama masa kerja maka semakin rendah stres kerja pada responden.

Hasil penelitian dapat diketahui bahwa responden dengan masa kerja 5-9 tahun dan mengalami stres kerja sedang sebanyak 5 responden $(71,4 \%)$ dan responden yang memiliki masa kerja 0-4 tahun sebanyak 3 responden (100\%). Sedangkan responden yang mengalami stres kerja tinggi dengan masa kerja 5-9 tahun sebanyak 2 responden $(28,6 \%)$ dan masa kerja $0-4$ tahun tidak terdapat responden yang mengalami stres kerja tinggi. Penelitian Sartika (2013) juga menunjukkan bahwa pedagang tradisional di Pasar Daya Kota Makasar yang memiliki masa kerja lebih rendah cenderung mengalami stres kerja tinggi.

Penelitian yang dilakukan oleh Saikhunuddin (2009) yang menyatakan bahwa terdapat hubungan yang kuat antara masa kerja perawat di ICU dengan tingkat stres kerja perawat. Perbedaan hasil penelitian tersebut dapat terjadi karena responden dalam penelitian di bagian packer membutuhkan banyak pengalaman guna menghadapi cara kerja dan lingkungan kerja yang berbeda dengan pekerjaan lain. Responden dalam penelitian tersebut harus dapat beradaptasi dengan lingkungan yang berdebu dan pekerjaan yang membutuhkan aktivitas fisik cukup berat.

\section{Analisis Hubungan Beban Kerja Mental dengan Stres Kerja di Bagian Packer}

Hasil uji statistik korelasi spearman adalah 0,667 yang artinya hubungan antara beban kerja mental dengan stres kerja di bagian packer ini kuat. Tanda positif $(+)$ menunjukkan hubungan searah yang artinya semakin tinggi beban kerja mental seorang pekerja maka akan semakin tinggi stres kerjanya.

Hasil penelitian menunjukkan bahwa sebagian besar responden mengalami stres kerja sedang dan beban kerja mental sedang yaitu sebanyak 8 responden $(88,9 \%)$, sedangkan 1 responden $(100 \%)$ mengalami stres kerja sedang dan beban kerja mental berat.

Beban kerja mental yang diterima di bagian packer ini misalnya membutuhkan ketelitian untuk membaca surat ijin pengeluaran semen karena setiap permintaan jumlah semen dari setiap distributor berbeda-beda. Selain ketelitian, di bagian packer ini membutuhkan fokus saat melakukan pekerjaannya, karena apabila seorang pekerja tidak fokus maka dalam menempatkan kantong semen ke alat pengisi semen apabila kurang tepat menempatkannya isian semen dapat keluar/menyembur ke arah pekerja.

Sesuai dengan penelitian yang dilakukan oleh Siringoringo, et al. (2011) tentang stres kerja, yang menyatakan bahwa ada hubungan antara beban kerja dengan stres kerja. Beban kerja merupakan salah satu tuntutan yang dibebankan oleh perusahaan kepada pekerja yang menjadi stressor dalam pekerjaan dan beban kerja berlebih atau terlalu sedikit merupakan pembangkit terjadinya stres (Munandar, 2006). Sesuai dengan penelitian Setiawan, et al (2013) bahwa pekerja harus menyelesaikan tugas berdasarkan waktu yang sudah ditetapkan oleh perusahaan. Responden di bagian packer melakukan pekerjaan yang sama setiap harinya sehingga mereka semakin terampil karena melakukan pekerjaan yang sama setiap hari dan tidak memeras otak. Setiap harinya pekerja di bagian packer melakukan pengepakan \pm 2000 kantong/ jam. Tuntutan jumlah ini yang memungkinkan terjadinya beban kerja mental bagi pekerja di bagian packer.

Tuntutan pekerjaan dan tuntutan waktu yang mengharuskan setiap pekerja di bagian packer melakukan pengepakan \pm 2000 kantong/ jam dapat 
menjadi stressor yang dapat menjadi salah satu penyebab terjadinya stres kerja di bagian ini. Akan tetapi, tidak semua pekerja menganggap tuntutan kerja ini sebagai sebuah stressor, tergantung persepsi individu terhadap pekerjaannya dan bagaimana mengelola tuntutan tersebut agar tidak menyebabkan stres kerja.

Sesuai dengan penelitian yang dilakukan oleh Susetyo et al. (2012) tentang pengaruh beban kerja mental dengan stres kerja, menyebutkan bahwa karyawan pembuat batik mengalami beban kerja mental tinggi (91\%). Diperoleh nilai R sebesar 0,428 , nilai $\mathrm{R}$ mempunyai arti bahwa $42,8 \%$ stres kerja karyawan dipengaruhi oleh beban kerja mental.

\section{SIMPULAN}

Hasil penelitian faktor individu dan beban kerja mental dengan stres kerja di bagian packer PT. X Tuban, responden dengan jumlah 10 orang, dapat disimpulkan bahwa sebagian besar responden berada pada rentang umur 21-40 tahun (60\%) dan memiliki masa kerja 5-9 tahun (70\%) dengan tingkat pendidikan Tamat SMA $(60 \%)$ dan berstatus menikah (60\%). Variabel yang mempunyai hubungan kuat dengan stres kerja adalah variabel beban kerja mental.

\section{DAFTAR PUSTAKA}

Andraeni, N.N., 2003. Pengaruh Stres Kerja terhadap Motivasi Kerja dan Kinerja Karyawan PT H. M. Sampoerna Tbk Surabaya. Tesis. Surabaya: Universitas Airlangga.

Anoraga, P., 2006. Psikologi Kerja. Jakarta: Rineka Cipta.

Astuti, G., 2015. Faktor-Faktor yang Berhubungan dengan Kejadian Stres Kerja pada Pengemudi Taksi New Atlas Semarang Tahun 2015. Skripsi. Semarang: Universitas Negeri Semarang.

Cox. T., Griffith, A., Gonzales, E., 2000. Research on Work Related Stress. Luxemburg: European Agency For Safety and Health.

Fitri, A., 2013. Analisis Faktor-Faktor yang Berhubungan dengan Kejadian Stres Kerja pada Karyawan Bank (Studi pada Karyawan Bank BMT). Jurnal Kesehatan Masyarakat Volume 2, Nomor 1, Tahun 2013. Semarang; Universitas Diponegoro.

Hanapi, L.K., 2014. Pengukuran Beban Kerja dengan
Metode NASA-Talk Load Index di CV. Gimera Jaya Bandung. Jurnal. Semarang; Universitas Dian Nuswantoro.

Herrianto, R., 2010. Kesehatan Kerja. Jakarta: Buku Kedokteran EGC.

Irkhami, F., 2015. Hubungan Tipe Kepribadian dan Stresor Lingkungan Kerja dengan Stres Kerja Pada Penyelam di PT. Advanced Offshore services. Skripsi. Surabaya: Universitas Airlangga.

Manuaba., 1998. Stress and Strain. Dalam: Bungan Rampai Ergononi Vol. I. Program Studi ErgonomiFisiologi Kerja Universitas Udayana Denpasar.

Munandar., 2006. Psikologi Industri dan Organisasi. Jakarta: UI Press.

Notoatmodjo, S., 2002. Metodologi Penelitian Kesehatan. Jakarta: CV. Sayung Seto.

Prabawati, R., 2012. Hubungan Beban Kerja Mental dengan Stres Kerja pada Perawat Bagian Rawat Inap RSJD Dr. R.M. Soedjarwadi Klaten. Skripsi, Surakarta; Universitas Sebelas Maret.

Prativi, L., 2013. Gambaran Stres Kerja dan Faktor-Faktor yang Memengaruhi Terjadinya Stres pada Pekerja di Operasi dan Produksi PT. Pertamina Geothermal Energy Area Kamojang Tahun 2012. Skrisi. Depok: Universitas Indonesia.

Ratnasari., 2009. Stres Pada Perawat di Instalasi Rawat Inap rumah Sakit Menur Surabaya. Skripsi. Surabaya: Universitas Airlangga.

Robbins, S., 2004. Teori Organisasi, Struktur, Desain, dan Aplikasi. (Alih Bahasa: Tim Indeks). New Jersey: Prentice-Hall.

Saikhunuddin., 2009. Hubungan Faktor Individu dengan Tingkat Stres Kerja Perawat di ICU RSUD Ibnnu Sina Kabupaten Gresik. Skripsi. Surabaya: Universitas Airlangga.

Setiawan, D., Sofiana, L., 2013. Faktor-Faktor yang Berhubungan dengan Stres Kerja di PT. Chanindo Pratama Piyungan Yogyakarta. Jurnal Kesehatan, ISSN 1979-7621, Vol. 6, No. 2. Desember 2013: 134-144. Yogyakarta: Universitas Ahmad Dahlan.

Siringoringo, E., Nontji, W., \& Hadju, V., 2010. Faktor-Faktor yang berhubungan dengan Stress Kerja Perawat di Ruang ICU RS Stella Maris Makassar. Skripsi. Makassar: Universitas Hasanuddin.

Suci, A., Rahman, A., Dewi, R., 2012. Analisis Stressor Pekerja Wanita dengan Pendekatan Structural Equation Modelling. Skripsi. Surabaya: Institut Teknologi Sepuluh Nopember Surabaya. 
Suisku, L., Smith., 2005. Work Stress. USA: Thomson Wadsworth.

Susetyo, J., Risma., Simanjuntak., Wibisono, R., 2012. Pengaruh Beban Kerja Mental dengan Menggunakan Metode Nasa-Task Load Index (TLX) terhadap Stres Kerja. Prosiding Seminar Nasional Aplikasi Sains dan Teknologi (SNAST) Periode III, ISSN: 1979-911X. Yogyakarta: Institut Sains \& Teknologi AKPRIND.

Tahir, N., 2015. Pengaruh Stres Kerja dan Kepuasan Kerja Terhadap Kinerja Karyawan PT. Pelindo IV (PERSERO) Cabang Makassar. Skripsi. Makassar: Universitas Hasanuddin.

Tarwaka., Sholichul., Sudiajeng, L., 2004. Ergonomi untuk Keselamatan Kesehatan Kerja dan Produktivitas. Surakarta: UNIBA Press.
Tarwaka., 2010. Ergonomi Industri, Dasar-Dasar Pengetahuan Ergonomi dan Aplikasi di Tempat Kerja. Surakarta: Harapan Press.

Tarwaka., 2015. Ergonomi Industri, Dasar-Dasar Pengetahuan Ergonomi dan Aplikasi di Tempat Kerja. Surakarta: Harapan Press.

Wati, D., 2013. Hubungan Antara Individual Arena dan Work Arena dengan Stres Kerja Pada Pekerja Pembuatan Offshore Pipeline and Mooring Tower (EPC3) Proyek Banyu Urip di PT. Rekayasa Industri, Serang - Banten Tahun 2013. Skripsi. Jakarta: Universitas Islam Negeri Syarif Hidayatullah.

Wijono, S., 2010. Psikologi Industri dan Organisasi Suatu Bidang Gerak Psikologi Sumber Daya Manusia. Jakarta: Kencana. 